\title{
Corpus Interruptus: Biotech Drugs, Insurance Providers and the Treatment of Breast Cancer
}

\author{
Jane E. Schultz
}

Published online: 20 July 2007

(C) Springer Science + Business Media B.V. 2007

Erratum to: Bioethical Inquiry

DOI: 10.1007/s11673-007-9045-6 (this issue)

The Journal of Bioethical Inquiry asked Amgen for permission to re-print images of the Neulasta advertisements discussed in the article by Jane Schultz entitled Corpus Interruptus: Biotech Drugs, Insurance Providers and the Treatment of Breast Cancer.
Amgen asked to see a copy of this article, and then refused to grant permission. Similar advertisements can be viewed at the following website: http://www. neulasta.com/patient/index.jsp

The online version of the original article can be found under doi:10.1007/s11673-007-9045-6.

J. E. Schultz $(\bowtie)$

Department of English,

Indiana University - Purdue University - Indianapolis, 425 University Blvd.,

Indianapolis, IN 46205, USA

e-mail: jschult@iupui.edu 